Published by LPMP Imperium

Journal homepage: https:/ / ejournal.imperiuminstitute.org/index.php/ AKURASI

\title{
Pengaruh Return on Asset, Earning Per Share, Price Earning Ratio Terhadap Return Saham
}

\section{Laras Safira \& Roy Budiharjo}

Fakultas Ekonomi \& Bisnis Universitas Mercu Buana, Jakarta, Indonesia

\author{
Research Paper \\ Financial Management
}

\begin{abstract}
This Research aims to know the influence of Return On Asset (ROA),Earning Per Share (EPS) and Price Earning Ratio (PER) to Stock Return of Insurance company listed on Indonesia Stock Exchange in 2013 - 2017. Data used is secondary data based on the annual report taken form Indonesia Stock Exchange website, company website, and othe support sources. Technique of data analysis is multiple linear regression, which is proceeded with SPSS 21. This study uses purposive sampling and 11 of 14 insurance sector companies listed in IDX used as a sample. The research result shows that Return On Asset (ROA), Earning Per Share (EPS) and Price Earning Ratio (PER) in 2013 - 2019 simultaneous and partially positive significantly affected by the stock return
\end{abstract}

Keywords:

Stock Return, Return On Asset, Earning Per Share, Price Earning Ratio
Received: 09 Apr 2021 Accepted: 25 Apr 2021

Online: 30 Apr 2021

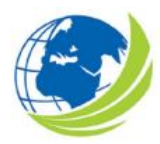

Akurasi: Jurnal Riset Akuntansi dan Keuangan, Vol 3, No.1, 2021, pp. $43-52$

eISSN 2685-2888

(c) The Author(s) 2021

DOI: https:/ / doi.org/ 10.36407/ akurasi.v3i1.325

\section{(c) (1)}

CC BY: This license allows reusers to distribute, remix, adapt, and build upon the material in any medium or format, so long as attribution is given to the creator. The license allows for commercial use. 


\section{PENDAHULUAN}

Perusahaan asuransi merupakan lembaga keuangan yang menghimpun dana berupa premi dari masyarakat. Perusahaan yang menjadikan premi sebagai pendapatan utama, pastinya perusahaan tersebut belum tentu dapat memenuhi kewajibannya dalam menanggung resiko serta menjaga kesehatan keuangan perusahaan. Kelangsungan hidup perusahaan dipengaruhi oleh banyak hal antara lain profitabilitas perusahaan itu sendiri. Dengan laba tersebut, perusahaan juga dapat membayar deviden kepada para pemegang sahamnya. Kemampuan tingkat pengembalian investasi inilah yang banyak diperhitungkan oleh para pemegang saham.

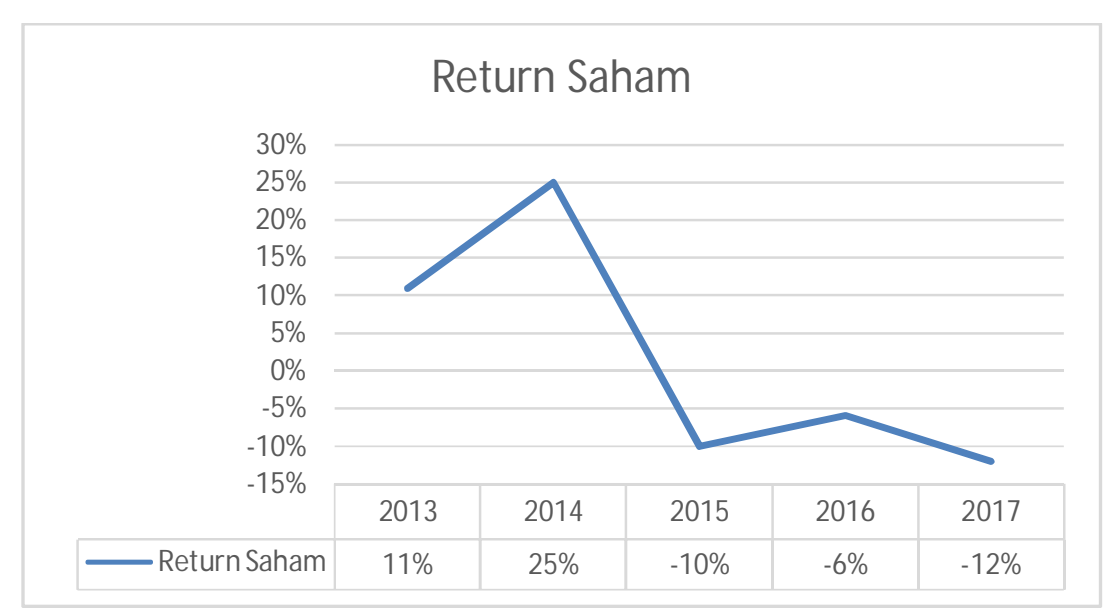

\section{Gambar 1.}

Return Saham rata-rata perusahaan asuransi yang listing di BEI 2013 - 2017

Gambar 1 menunjukan bahwa return saham dari setiap perusahaan asuransi yang listed di BEI setiap tahunnya mengalami fluktuasi. Return saham rata-rata tertinggi terdapat pada tahun 2013 sebesar 11\%. Sedangkan return saham rata-rata terendah terdapat pada tahun 2017 sebesar -12\% yang disebakan terjadinya penurunan return saham pada PT Asuransi Bintang, Tbk. Perkembangan return saham rata-rata perusahaan asuransi cenderung mengalami fluktuatif. Dari Gambar 1 tersebut bisa disimpulkan bahwa return saham bisa mengalami kenaikan atau bahkan penurunan yang drastis. Melihat fakta bahwa tidak ada kepastian mengenai return yang akan didapatkan oleh investor ketika melakukan investasi saham, tentu seorang investor tidak ingin melakukan kesalahan dalam pengambilan keputusan investasi. Oleh karena itu, perlu diketahui faktor-faktor yang mempengaruhi return saham, sehingga harapan untuk memperoleh return yang maksimal dapat tercapai.

Kenaikan dan penurunan return saham suatu perusahaan secara umum dapat dipengaruhi oleh faktor internal (lingkungan mikro) yaitu kinerja perusahaan dan faktor eksternal (lingkungan makro) diantaranya yaitu kebijakan pemerintah dan daya beli. Kinerja perusahaan terlihat dari tampilan laporan keuangan yang meningkat. Sehingga kondisi dan posisi keuangan akan mengalami perubahan. Dengan perubahan posisi keuangan ini, hal ini akan mempengaruhi return saham perusahaan. Tingginya return saham suatu perusahaan, menunjukan bahwa perusahaan tersebut memiliki kinerja perusahaan yang baik sehingga memberikan keyakinan bahwa perusahaan akan memberikan efek positif terhadap saham yang ditanamkan investor. (Mentari, 2018). 
Return saham atau tingkat pengembalian saham perusahaan cenderung berfluktuatif, dimana kadang kala terjadi keuntungan (bernilai positif) kadang pula terjadi kerugian (bernilai negatif). Berbagai keadaan yang terjadi pada Return saham tersebut tentunya ada faktor yang mempengaruhi. Hal tersebut sebagaimana dikatakan oleh Sudarsono dan Sudiyatno (2016: 30) menyatakan bahwa banyak faktor yang mempengaruhi Return saham, diantaranya Faktor-faktor fundamental tersebut yakni Return On Asset (ROA), Earning Per Share (EPS) dan Price Earning Ratio (PER).

Return On Asset (ROA) dalam penelitian ini adalah mengukur perbandingan antara laba bersih setelah dikurangi beban bunga dan pajak (Earning After Taxes/ EAT) yang dihasilkan dari kegiatan pokok perusahaan dengan total aktiva (assets) yang dimiliki perusahaan. (Astrid, Ariawan \& Pemy, 2018). Hubungan antara Return On Asset (ROA) dengan return saham sebagaimana dijelaskan oleh Şebnem Er dan Bengü Vuran (2012) bahwa Return On Asset (ROA) dapat menjadi faktor yang dapat meningkatkan nilai perusahaan yang diukur dengan return saham. Earning Per Share (EPS) adalah salah satu rasio pasar yang merupakan hasil atau pendapatan yang akan diterima oleh para pemegang saham untuk setiap lembar saham yang dimilikinya atas keikutsertaan dalam perusahaan. Keterkaitan antara Earning Per Share (EPS) dengan return saham sebagaimana dijelaskan oleh Nathaniel (2008:41) bahwa investor akan mengharapkan manfaat dari investasinya dalam bentuk laba per lembar saham, sebab Earning per Share (EPS) yang akan didistribusikan kepada investor saham.

\section{KAJIAN PUSTAKA}

\section{Signaling Theory}

Teori sinyal (Signaling Theory) pertama kali diperkenalkan oleh Spence di dalam penelitiannya yang berjudul Job Market Signaling. Spence (1973) mengemukakan bahwa isyarat atau signal memberikan suatu sinyal, pihak pengirim (pemilik informasi) berusaha memberikan potongan informasi relevan yang dapat dimanfaatkan oleh pihak penerima. Penerima kemudian akan menyesuaikan perilakunya sesuai dengan pemahamannya terhadap sinyal tersebut. Secara garis besar, signaling theory merupakan penyediaan informasi keuangan yang diumumkan perusahaan kepada para investor sebagai bahan pengambilan keputusan investasi. Pemeringkatan perusahaan yang telah go-public lazimnya didasarkan pada analisis rasio keuangan ini. Analisis ini dilakukan untuk mempermudah interpretasi terhadap laporan keuangan yang telah disajikan oleh manajemen. (Kretarto, 2001:53)

\section{Hubungan ROA terhadap Return Saham}

Return On Asset (ROA) merupakan ukuran perusahaan didalam menghasilkan keuntungan (return) dengan memanfaatkan aktiva yang dimiliknya (Tandelilin, 2010:378). Dengan meningkatnya Return On Asset (ROA) maka kinerja perusahaan yang ditinjau dari profitabilitas semakin baik. Tandelilin (2010:315) berpendapat bahwa nilai ROA berdampak pada return saham, karena ROA mampu menunjukkan return atas keuntungan yang diperoleh perusahaan dari hasil investasi yang dilakukan investor dan berfungsi untuk menjelaskan kinerja perusahaan. dalam mengelola aset dan memperoleh keuntungan. Sejalan dengan itu, Kasmir (2012:202) mengatakan bahwa semakin tinggi total ROA berarti kinerja perusahaan baik dalam mengelola aset untuk mendapatkan keuntungan maupun peningkatan nilai Return on Assets profitabilitas akan mempengaruhi return atas saham yang diperoleh. Hal ini akan menarik bagi investor untuk memiliki saham tersebut karena 
peningkatan profitabilitas ini akan dinikmati juga oleh pemegang saham. Ketertarikan investor ini akan meningkatkan permintaan saham perusahaan maka harga akan cenderung meningkat yang diikuti dengan return saham yang meningkat pula. Pernyataan ini didukung oleh Kasmiati \& Santosa (2019), Sutriani (2014), Zulkarnaen et al. (2016) Andi (2015) \& Anwar (2016) dalam penelitiannya menyatakan bahwa ROA berpengaruh terhadap Return Saham.

H1: ROA berpengaruh positif terhadap Return Saham

\section{Hubungan EPS terhadap Return Saham}

Earning Per Share (EPS). adalah salah satu rasio pasar yang merupakan hasil atau pendapatan yang akan diterima oleh para pemegang saham untuk setiap lembar saham yang dimilikinya atas keikutsertaan dalam perusahaan. Keterkaitan antara Earning Per Share (EPS) dengan return saham sebagaimana dijelaskan oleh Nathaniel (2008:41) bahwa investor akan mengharapkan manfaat dari investasinya dalam bentuk laba per lembar saham, sebab Earning per Share (EPS) yang akan didistribusikan kepada investor saham. Pernyataan ini didukung oleh Anwar (2016), Ida Ayu (2017) dan Laurens (2018) dalam penelitiannya menyatakan bahwa EPSberpengaruh terhadap Return Saham.

H2: EPS berpengaruh positif terhadap Return Saham

\section{Hubungan PER terhadap Return Saham}

Malintan (2012:7) menjelaskan bahwa PER digunakan oleh para investor untuk memprediksi kemampuan perusahaan dalam menghasilkan laba di masa yang akan datang. Jika harga saham semakin tinggi maka selisih harga saham periode sekarang dengan periode sebelumnya semakin besar, sehingga capital gain juga semakin meningkat. Pernyataan ini didukung oleh Cokorda Indah \& Henny (2016) \& Astrid, Ariawan dan Pemmy (2018) dalam penelitiannya menyatakan bahwa PER berpengaruh terhadap Return Saham.

H3: PER berpengaruh terhadap Return Saham

\section{METODE PENELITIAN}

Penelitian ini dilakukan pada perusahaan asuransi yang telah terdaftar (listed) di Bursa Efek Indonesia (BEI) Periode 2013 - 2017. Data yang digunakan berupa laporan keuangan perusahaan asuransi yang diambil melalui website Bursa Efek Indonesia yaitu www.idx.co.id. Metode statistik yang digunakan untuk menganalisis data dan menguji hipotesis yaitu dengan menggunakan statistik deskriptif, uji asumsi klasik dan uji hipotesis dengan menggunakan bantuan perangkat lunak Microsoft Excel dan SPSS (Statistical Package for Social Sciences).

\section{Pengukuran}

Menurut Ang (1997:97) konsep return (kembalian) adalah tingkat keuntungan yang dinikmati oleh pemodal atas suatu investasi yang dilakukannya. Return saham atau pengembalian saham merupakan salah satu aspek terpenting dalam melakukan analisis investasi. Return saham adalah income yang diperoleh oleh pemegang saham sebagai hasil dari investasinya diperusahaan tertentu. Pengukuran Return saham pada penelitian ini di hitung dengan menggunakan rumus (Jogiyanto, 2012:206) sebagai berikut: 


$$
\text { Return Saham }=\frac{\text { Saham }_{t}-\text { Saham }_{t-1}}{\text { Saham }_{t-1}} \times 100 \%
$$

Brigham dan Houston (2011: 90) Rasio laba bersih terhadap total aktiva mengukur pengembalian atas total aktiva (ROA) setelah bunga dan pajak. Return On Assets (ROA) mampu mengukur kemampuan perusahaan manghasilkan keuntungan pada masa lampau untuk kemudian diproyeksikan di masa yang akan datang. Pengukuran atau rumus dari Return On Asset mengacu pada Hermuningsih (2012:237) yang dijabarkan berikut ini:

$$
R O A=\frac{\text { Laba Bersih }}{\text { Total Aktiva }} \times 100 \%
$$

Komponen penting yang harus diperhatikan dalam analisis perusahaan adalah laba per lembar saham atau dikenal sebagai Earning Per Share (EPS). Earning Per Share (EPS) adalah rasio yang mencerminkan kemampuan perusahaan dalam menghasilkan laba untuk setiap lembar saham yang beredar (Darmaji, 2011: 139). Adapun rumus yang digunakan untuk menentukan EPS menurut Fabozzi (2003: 361) adalah sebagai berikut:

$$
E P S=\frac{\text { Laba Bersih }}{\text { Jumlah Saham Beredar }}
$$

Price earning ratio atau juga disebut sebagai earning multiplier. Informasi PER mengindikasikan basarnya rupiah yang harus dibayarkan investor untuk memperoleh satu rupiah earning perusahaan. (Tandelilin, 2007:243). Secara matematis, kita dapat mengestimasi nilai intrinsik saham perusahaan sebagai berikut:

$$
P E R=\frac{\text { Harga Saham }}{E P S}
$$

\section{HASIL DAN PEMBAHASAN}

\section{Hasil Analisis Deskriptif}

Jumlah data yang diolah dala penelitian ini adalah 55 sampel yang terdiri dari 11 perusahaan yang dijadikan sampel selama 5 tahun yang terdiri dari data variabel Return On Asset (ROA), Earning Per Share ( EPS) dan Price Earning Ratio (PER) terhadap Return Saham.

Tabel 1.1

\section{Statistik Deskriptif}

\begin{tabular}{crrrr}
\hline & Minimum & Maximum & \multicolumn{1}{c}{ Mean } & \multicolumn{1}{c}{$\begin{array}{c}\text { Std. } \\
\text { Deviation }\end{array}$} \\
\hline ROA & -0.100 & 0.260 & 0.063 & 0.052 \\
EPS & 0.000 & 852.470 & 208.173 & 192.980 \\
PER & -1.580 & 31.090 & 10.529 & 7.684 \\
Return Saham & -1.500 & 0.690 & 0.024 & 0.389 \\
\hline
\end{tabular}

Sumber: Output spss 21 
Berdasarkan tabel 1 dapat diketahui besarnya Return On Asset (ROA) berkisar antara $-0,10$ (10\%) dan 0,26 (26\%) dengan nilai mean sebesar 0,0634 (6\%) dan standar deviasi sebesar 0,05192 (5\%). Return On Asset terendah adalah PT Asuransi Harta Aman Pratama, Tbk pada tahun 2017 yaitu sebesar -0,10 (10\%), hal ini dikarenakan return on asset pada perusahaan tersebut rendah ditahun 2017. Perusahaan dengan nilai ROA tertinggi adalah PT Panin Life, Tbk yaitu sebesar 0,26 (26\%) pada tahun 2015. Pada tahun 2017, PT Asuransi Harta Aman Pratama, Tbk mengalami kerugian sebesar 41,42 Miliyar Rupiah yang menyebabkan rendahnya nilai return on asset sebesar -0,10 (-10\%). Sedangkan PT Panin Life, Tbk memiliki return on asset yang tinggi dikarenakan perushaan tersebut memiliki aktiva yang yang meningkat dibanding tahun sebelumnya.

Earnings per share (EPS) berkisar antara -49,31 (-49\%) dan 852,47 (852\%), dengan nilai mean sebesar 208,1725 (208\%) dan standar deviasi sebesar 192,98035 (192\%). Perusahaan yang memiliki EPS terendah adalah PT Asuransi Harta Aman Pratama, Tbk pada tahun 2017 yaitu sebesar-49,31 (-49\%). EPS PT Asuransi Harta Aman Pratama, Tbk pada tahun 2014 merupakan yang terkecil diantara EPS perusahaan lainnya ditahun 2013 - 2017. Perusahaan yang memiliki EPS tertinggi adalah PT Asuransi Lippo G.Insurance, Tbk pada tahun 2014 yaitu sebesar 852,47 (852\%). Hal ini dikarenakan sepanjang tahun 2014 perusahaan ini mendapatkan laba yang besar dibanding tahun sebelumnya.

Price Earning Ratio (PER) berkisar antara -1,58 (-1\%) dan 31,09 (31\%) dengan nilai mean sebesar 10,5294 (10\%) dan standar deviasi sebesar 7,68429 (7\%). Price Earning Ratio terendah adalah PT Asuransi Harta Aman Pratama, Tbk pada tahun 2017 yaitu sebesar -1,58 (-1\%), hal ini dikarenakan mengalami kerugian sebesar 41,42 Miliyar Rupiah yang menyebabkan rendahnya nilai PER pada perusahaan tersebut, dan nilai PER tertinggi adalah PTPanin Life, Tbk yaitu sebesar 31,09 (31\%) pada tahun 2014 dikarenakan mengingkatnya harga saham dari tahun sebelumnya.

Return Saham memiliki rata-rata 0,0244 satuan dengan tingkat rata-rata penyimpangan atau standar deviasi sebesar 0,38949 satuan. Nilai Return Saham tertinggi (maximum) adalah 0,69 sedangkan nilai terendah (minimum) adalah -1,50. Hal ini menunjukkan bahwa data pada variabel Return Saham memiliki sebaran yang besar, karena standar deviasi lebih besar dari nilai mean-nya, sehingga data dikatakan kurang bagus.

\section{Uji Goodness of Fit}

Model regresi harus dikatakan baik untuk digunakan dalam proses peramalan, untuk menguji baik tidaknya model regresi dapat menggunakan uji $\mathrm{F}$ dengan menggunakan tabel ANOVA. Nilai significant of probability dari nilai $F$ hitung adalah 0,003 lebih kecil dari level of significant sebesar 0,05 atau 5\%, maka dapat diambil kesimpulan bahwa Ho ditolak dan Ha diterima. Berdasarkan kesimpulan tersebut maka model regresi yang digunakan sudah tepat, oleh sebab itu, model yang terbentuk secara statistik sudah baik untuk digunakan dalam menilai perubahan variabel dependen. Berdasarkan Tabel 2 dapat diketahui bahwa nilai Adjusted RSquare (R2) dari model regresi yang terbentuk dalam penelitian ini adalah sebesar 0.189 yang menunjukan bahwa kemampuan variabel independen (ROA, EPS, PER) dalam menjelaskan variabel dependen Return Saham adalah sebesar 18,9\% dan sisanya sebesar $81,8 \%$ dijelaskan oleh sebab sebab atau variabel lain diluar model. 
Tabel 2.

Model Regresi

\begin{tabular}{lrrrr}
\hline & B & Std. Error & \multicolumn{2}{c}{ S } \\
\hline (Constant) & -0.378 & 0.113 & -3.334 & 0.002 \\
ROA & 2.053 & 0.956 & 2.146 & 0.037 \\
EPS & 0.001 & 0.000 & 2.378 & 0.021 \\
PER & 0.014 & 0.007 & 2.113 & 0.039
\end{tabular}

Adj. R Square $\quad 0.189$

F-Statistics $\quad 5.198$

Sig $\quad 0.003$

Sumber: data lapangan, diolah

Hasil analisis menunjukkan bahwa dar tiga variabel yang diuji seluruhnya signifikan pada level $5 \%$ (Sig <0.05), sehingga seluruh hipotesis terdukung,

\section{Pembahasan}

Studi ini menemukan bahwa ROA memiliki efek positif dan signifikan terhadap return saham. Dengan demikian, ROA dapat dijadikan sebagai sinyal positif untuk saham dalam bentuk keuntungan bagi investor. Semakin tinggi ROA maka akan semakin tinggi juga kemungkinan kembali saham berikutnya. Studi ini sejalan dengan pendapat Subrahmanyan (2014) dan Brown \& Reiley (2012) berpendapat bahwa profitabilitas adalah salah satu variabel penting yang dipertimbangkan oleh investor. Investor ekuitas menjadikan profitabilitas sebagaisalah satu indikator kunci karena mereka berorientasi jangka panjang dalam investasinya, sedangkan Santosa (2010) berpendapat bahwa profitabilitas sebagai sinyal hasil dividen yang dijamin sebagai komponen pengembalian selain keuntungan modal. Secara empiris, Kasmiati \& Santosa (2019), Sutriani (2014) dan Zulkarnaen et al. (2016) berpendapat bahwa profitabilitas berpengaruh positif terhadap return saham.

Sejalan dengan hipotesis yang diajukan, EPS juga terbukti signifikan mempengaruhi return saham. Dengan demikian, semakin tinggi EPS maka kemungkinan keuntungan yang akan diperoleh dari return saham juga akan semakin meningkat. Laurens (2018) menjelaskan bahwa para investor yang akan melakukan investasi dengan membeli saham di pasar modal akan menganalisis terlebih dahulu kondisi perusahaan investasi tersebut sehingga memberikan keuntungan (return). Mendapatkan return (keuntungan) merupakan tujuan utama dari aktivitas perdagangan investor di pasar modal, oleh karena itu EPS juga memiliki pengaruh yang signifikan terhadap return saham (Anwar, 2016; Hermawan, 2012; Ida Ayu, 2017).

Price Earning Ratio (PER) terbukti berpengaruh positif dan signifikan terhadap return saham sehingga dapat dinyatakan bahwa semakin tinggi PER maka akan semakin besar kemungkinan return saham di masa depan. PER memiliki fokus pada laba bersih yang dihasilkan perusahaan, dapat diketahui apakah harga saham tersebut dianggap wajar atau tidak nyata, bukan perkiraan. PER merupakan rasio pasar adalah rasio yang digunakan untuk mengetahui kinerja keuangan perkembangan suatu perusahaan. Price Earning Ratio yang tinggi berarti bahwa investor bersedia membayar lebih untuk saham-mungkin karena perusahaan diharapkan memiliki pertumbuhan yang lebih tinggi daripada rata-rata 
pertumbuhan pendapatan masa depan. Sebaliknya, jika investor meyakini prospek pertumbuhan laba yang akan datang tidak baik, price earning ratio relatif rendah.

\section{KESIMPULAN}

Tujuan dari penelitian ini adalah untuk mengetahui pengaruh ROA, EPS \& PER terhadap Return Saham dari Perusahaan Asuransi yang terdaftar di Bursa Efek Indonesia (BEI) tahun 2013 - 2017. Berdasarkan data yang telah dianalisis dengan menggunakan metode analisis regresi berganda maka dapat ditarik kesimpulan bahwa baik ROA, EPS dan PER seluruhnya terbukti berpengaruh signifikan terhadap return saham. Implikasi temuan ini adalah ketiga factor ini dapat dijadikan pertimbangan oleh investor untuk memprediksi return saham di masa depan, terutama di perusahaan sector ansuransi.

Penelitian ini dimasa yang akan datang diharapkan dapat menyajikan hasil penelitian yang lebih berkualitas lagi dengan adanya beberapa masukan mengenai beberapa hal yang dapat menjadi acuan pembaharuan penelitian diantaranya: pertama, penelitian selanjutnya, sebaiknya menambah variabel guna menyempurnakan penelitian ini. Kedua, penelitian ini masih terbatas ruang lingkupnya pada perusahaan asuransi. Hal ini menyebabkan jumlah sampel penelitian menjadi terbatas. Penelitian selanjutnya diharapkan menggunakan sampel yang lebih luas, dengan demikian, maka sampel menjadi lebih representative terhadap populasinya, serta hasil penelitian yang diperoleh akan lebih bermanfaat karena menunjukkan kecenderungan dari populasi yang ada. Ketiga, bagi para investor dan calon investor yang akan berinvestasi saham hendaknya memfokuskan dalam berinvestasi ingin memperoleh manfaat berupa Return Saham, dengan begitu akan lebih mudah dalam menentukan akan menanam saham di perusahaan yang mana.

\section{REFERENSI}

Ang, R. (1997). Buku Pintar Pasar Modal Indonesia. Jakarta: Mediasoft Indonesia.

Anwar, M. (2016). Impact of Firms' Performance on Stock Returns (Evidence From Listed Companies of FTSE- 100 Index London, UK). Global Journal of Management and Bussiness Research: D Accounting and Auditing, Vol. 16, Issues 1.

Astrid, A. \&. (2018). Pengaruh ROA, EPS, dan PER Terhadap Return Saham Perusahaan Manufaktur Sub Sektor Industri Rokok yang terdaftar di BEI. Jurnal Ilmu Manajemen Universitas Tadulako, 91 - 102.

Brigham, E. F. (2014). Dasar-dasar Manajemen Keuangan. Jakarta: Salemba Empat.

Brown, K. C, Reilly, F. K. (2012). Analysis of Investments and Management of Portfolios. 10th Edition. USA: Thomson South-Western.

Cahyaningrum, Y. W. (2017). Pengaruh Earning Per Share, Price To Book Value, Return On Asset, dan Return On Equity Terhadap Harga Saham Sektor Keuangan. Surakarta: Universitas Sebelas Maret.

Halim, A. (2005). Analisis Investasi. Edisi Dua. Jakarta: Salemba Empat.

Hartono, P. R. (2009). Analisis Hubungan Profitabilitas dengan Pergerakan Harga Saham pada Sektor Usaha Perbankan di Bursa Efek Indonesia. Journal of Applied Finance \& Accounting Vol.2, pp. 51- 56.

Henry, S. (2000). Basic Pengambilan keputusan Bisnis. Jakarta: Salemba Empat.

Hermawan, D. A. (2012). Pengaruh debt to equity ratio, Earning Per Share, dan net profit margin terhadap return saham. Management Analysis Journal, 1(5), 1-7

Hermuningsih, S. (2012). Pengantar Pasar Modal Indonesia. Yogyakarta: UPP STIMYKPN.

Husnan, S. (1998). Dasar-dasar Teori Portofilio dan Analisis Sekuritas, Edisi Kedua. Yogyakarta: UPP-AMP YKPN.

Jogiyanto, H. (2010). Teori Portofolio dan Analisis Investasi Edisi Ketujuh. Yogyakarta: BPFE. 
Jogiyanto, H. (2013). Teori Portofolio dan Analisis Investasi Edisi Kedepalan. Yogyakarta: BPFE.

Kasmiati, M. and Santosa, P. W. (2019). The effect of earning information, cash flow components, and financing decision on stock returns: empirical evidence on Indonesia stock exchange, Journal of Economics, Business and Accountanc y Ventura, 16(2), 171-185

Kasmir. (2015). Analisis Laporan Keuangan . Jakarta: Rajawali Pers.

Laurens, S. (2018). Influence Analysis of DPS, EPS, and PBV toward Stock Price and Return. The Winners, 19(1), 21-29.

Lestari, K. d. (2016). Analisis Likuiditas, Leverage, Profitabilitas, Aktivitas, Ukuran Perusahaan, Dan Penilaian Pasar Terhadap Return Saham (Pada Perusahaan Real Estate Dan Property Di BEI) Periode Tahun 2009 - 2014. Semarang: Universitas Pandanaran.

Mayuni, I. A. (2017). Pengaruh ROA, Firm Size, dan PER terhadap Return Saham Perusahaan Sektor Manufaktur di BEI.

Nathaniel, N. (2008). Analisis Faktor-Faktor yang Mempengaruhi Return Saham. Universitas Dipenogoro Semarang.

Nurhayati, N. E. (2018). Pengaruh Return On Asset, Return On Equity, dan Earning Per Share Terhadap Return Saham Studi Empiris Perusahaan Manufaktu Sub Sektor Food\&Baverage Yang Terdaftar di BEI (2011-2016). Jakarta.

Prakoso, R. (2016). Analisis Faktor-faktor Yang Mempengaruhi Return Saham (Studi Empiris Pada Perusahaan Manufaktur Yang Go Public di Bursa Efek Indonesia Tahun 20112014). Surakarta: Universitas Muhammadiyah.

Puspitadewi, C. I. (2016). Pengaruh DER, ROA, PER, dan EVA Terhadap Return Saham Pada Perusahaan Food and Beverage Di BEI. Bali: Universitas Udayana.

Ravitasari, A. d. (2018). Pengaruh Return On Asset, Earning Per Share, Price Earning Ratio Terhadap Return Saham Perusahaan Manufaktur Sub Sektor Industri Rokok Yang Terdaftar Di Bursa Efek Indonesia. Gorontalo: Universitas Ichsan.

Santosa, P. W. (2019). Financial performance, exchange rate and stock return: Evidence from manufacturing sector. Jurnal Manajemen Teknologi, 18(3), 205-217.

Saranggih, L. J. (2018). The Effect Of Return On Asset (ROA), Return On Equity (ROE), and Debt Equity Ratio (DER) on Stock Return in Wholesale and Retail Trade Companies Listed in Indonesia Stock Exchange . International Journal of Sience and Research Methodology, Vol. 8, Issues 3.

Sophiariyani, N. M. (2016). Profitabilitas, Solvabilitas Dan Return Saham Perusahaan Indeks Saham Syariah Indonesia. Surabaya: STIE Perbanas.

Subrahmanyam, K.R. (2014). Financial thStatement Analysis, Ed. 11, New York: M cGraw Hill.

Sudarsono, B. d. (2016). Jurnal Bisnis dan Ekonomi, Vol. 23 No. 1. Faktor-Faktor yang mempengaruhi return saham pada perusahaan property dan real estate yang terdaftar di BEI., 30.

Sutriani, A. (2014). Pengaruh Profitabilitas, Leverage, dan Likuiditas Terhadap Return Saham dengan Nilai Tukar Sebagai Variabel Moderasi pada Saham LQ-45, Journal of Business and Banking, 4(1), 67-80.

Sutrisno, E. (2012). Manajemen Keuangan: Teori, Konsep, dan Aplikasi (Edisi Ke Delapan). Yogyakarta: Ekonisia.

Suwardjono. (2014). Teori Akuntansi: Perekayasaan Pelaporan Keuangan, Edisi ketiga. Yogyakarta.

Tamuntuan, U. (2015). Analysing The Effect Of Return On Equity, Return On Assets And Earning Per Share Toward Share Price: An Emperical Study Of Food And Beverage Companies Listed On Indonesia Stock Exchange.

Wijaya, J. A. (2015). The Effect of Financial Ratios toward Stock Return among Indonesian Manufacturing Companies. International Bussiness Management Program Petra Christian Universtias, Vol. 3, No.2. 
Wild, J. K. (2005). Analisis Laporan Keuangan. Edisi Kedepalan. Buku Kesatu. Alih Bahasa: Yanivi \& Nurwahyu. Jakarta: Salemba Empat.

Zulkarnaen, A. H., Syamsun, M. \& Maulana, T. N. A. (2016). Analysis of Fundamental and Technical Factors to Stock Price on Residential Property Sector Companies Listed in Indonesia Stock Exchange, International Journal of Scientific and Research Publications, $6(12), 315-319$

\section{DECLARATIONS}

\section{Funding}

The authors received no financial support for the research and publication of this article.

\section{Conflicts of interest/ Competing interests:}

The authors have no conflicts of interest to declare that are relevant to the content of this article.

Data, Materials and/ or Code Availability:

Data sharing is not applicable to this article as no new data were created or analyzed in this study.

\section{Notes on Contributor}

Laras Safira \& Roy Budiharjo merupakan Dosen di Fakultas Ekonomi dan Bisnis, Universitas Mercu Buana Jakarta.

\section{How to cite this Article}

Safira, L., \& Budiharjo, R. (2021). Pengaruh Return on Asset, Earning Per Share, Price Earning Ratio Terhadap Return Saham. AKURASI: Jurnal Riset Akuntansi Dan Keuangan, 3(1), 43 - 52. 